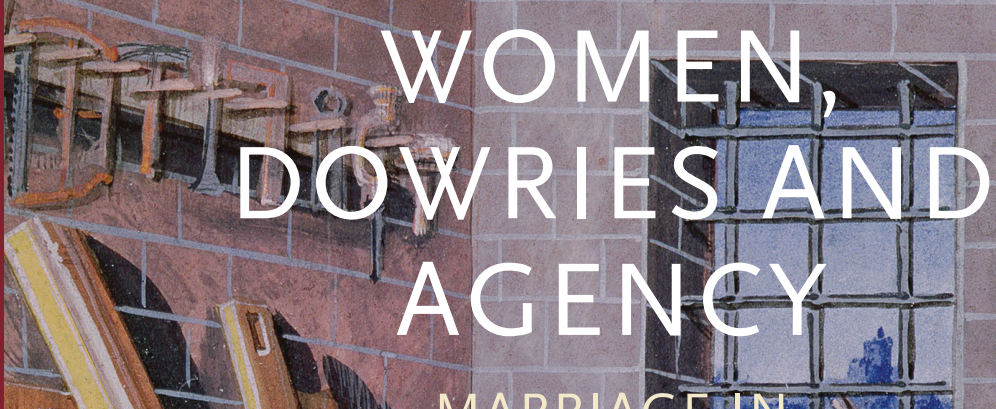

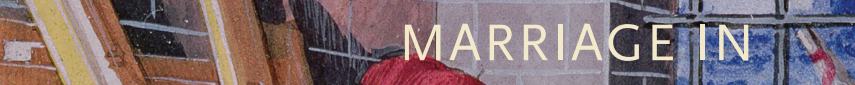

FIFTEENTH-CENTURY VALENCIA

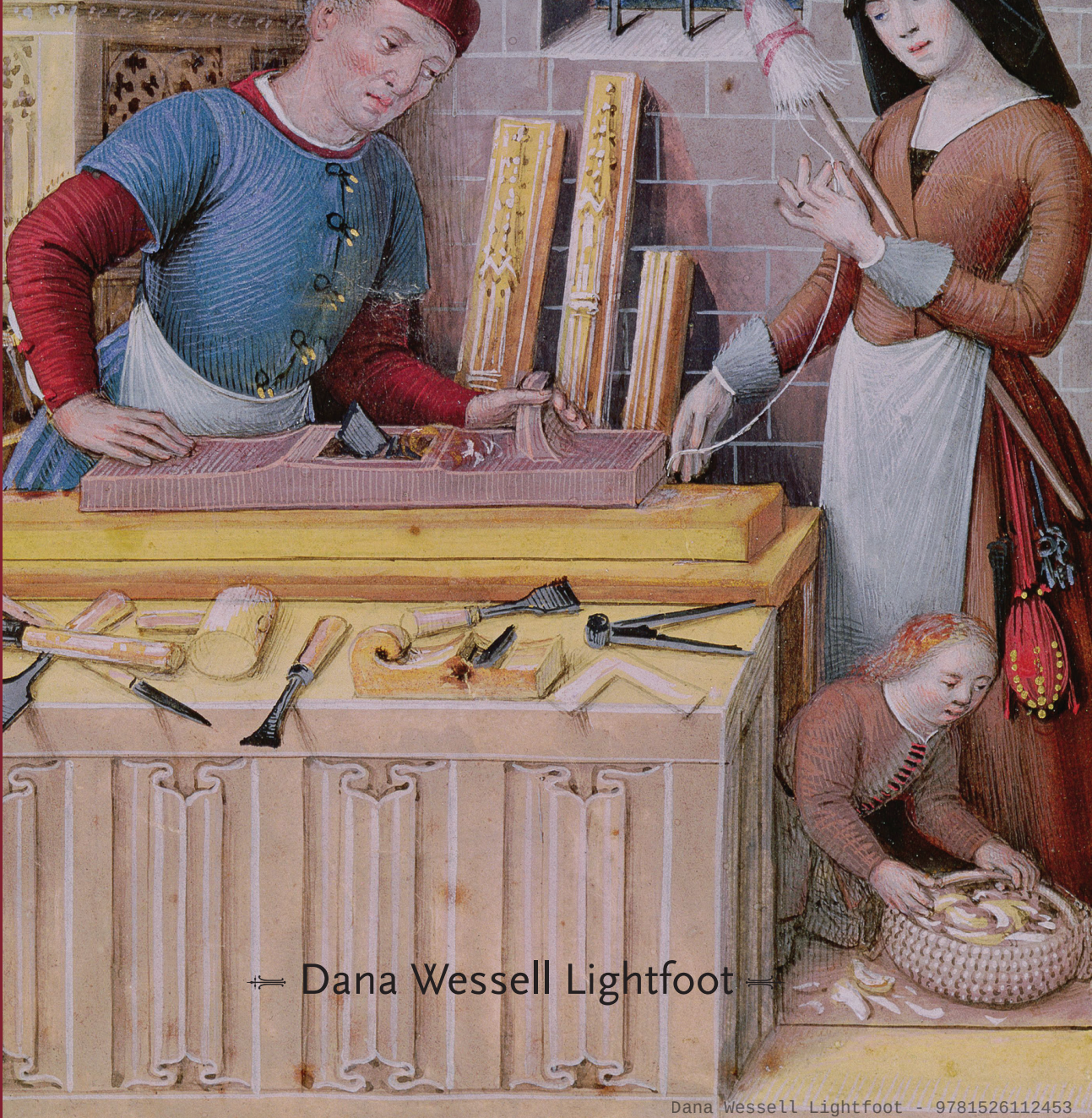




\title{
GENDER IN HISTORY
}

\author{
Series editors: \\ Lynn Abrams, Cordelia Beattie, Pam Sharpe and Penny Summerfield
}

\begin{abstract}
$\Longleftarrow$
The expansion of research into the history of women and gender since the 1970 s has changed the face of history. Using the insights of feminist theory and of historians of women, gender historians have explored the configuration in the past of gender identities and relations between the sexes. They have also investigated the history of sexuality and family relations, and analysed ideas and ideals of masculinity and femininity. Yet gender history has not abandoned the original, inspirational project of women's history: to recover and reveal the lived experience of women in the past and the present.

The series Gender in History provides a forum for these developments. Its historical coverage extends from the medieval to the modern periods, and its geographical scope encompasses not only Europe and North America but all corners of the globe. The series aims to investigate the social and cultural constructions of gender in historical sources, as well as the gendering of historical discourse itself. It embraces both detailed case studies of specific regions or periods and broader treatments of major themes. Gender in History books are designed to meet the needs of both scholars and students working in this dynamic area of historical research.
\end{abstract}

\section{Women, dowries and agency}

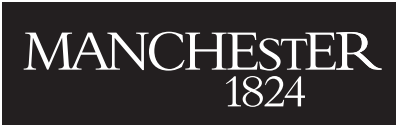

Manchester University Press 
Love, intimacy and power: marital relationships in Scotland, 1650-1850

Katie Barclay

(Winner of the 2012 Women's History Network Book Prize)

Modern women on trial: sexual transgression in the age of the flapper

Lucy Bland

Modern motherhood: women and family in England, c. 1945-200o

Angela Davis

Jewish women in Europe in the Middle Ages: a quiet revolution Simha Goldin

The shadow of marriage: singleness in England, 1914-60 Katherine Holden

Women, travel and identity: Journeys by rail and sea, 1870-1940 Emma Robinson-Tomsett

Imagining Caribbean womanhood: race, nation and beauty contests, 1929-70 Rochelle Rowe

Infidel feminism: secularism, religion and women's emancipation, England 1830-1914 Laura Schwartz

Being boys: working-class masculinities and leisure Melanie Tebbutt

Queen and country: Same sex desire in the British Armed Forces, 1939-45 Emma Vickers

The 'perpetual fair': gender, disorder and urban amusement in eighteenth-century London

Anne Wohlcke 


\title{
WOMEN, DOWRIES AND AGENCY MARRIAGE IN FIFTEENTH- CENTURY VALENCIA
}

\section{$\Longleftarrow$ Dana Wessell Lightfoot $\Longleftarrow$}

\author{
Manchester University Press \\ Manchester and New York \\ distributed in the USA exclusively by Palgrave Macmillan
}




\section{Copyright () Dana Wessell Lightfoot 2013}

The right of Dana Wessell Lightfoot to be identified as the author of this work has been asserted by her in accordance with the Copyright, Designs and Patents Act 1988.

Published by Manchester University Press

Oxford Road, Manchester M13 9NR, UK

and Room 400, 175 Fifth Avenue, New York, NY 10010, USA

www.manchesteruniversitypress.co.uk

Distributed exclusively in the USA by Palgrave

175 Fifth Avenue, New York,

NY 10010, USA

Distributed exclusively in Canada by UBC Press

University of British Columbia, 2029 West Mall,

Vancouver, BC, Canada v6T 1Z2

British Library Cataloguing-in-Publication Data

A catalogue record for this book is available from the British Library

Library of Congress Cataloging-in-Publication Data applied for

ISBN 978 o 719089466 hardback

First published 2013

The publisher has no responsibility for the persistence or accuracy of URLs for any external or third-party internet websites referred to in this book, and does not guarantee that any content on such websites is, or will remain, accurate or appropriate.

Typeset in Minion with Scala Sans display by

Koinonia, Manchester 